\title{
TABLE OF TREATIES, CONVENTIONS AND OTHER INSTRUMENTS
}

\section{TREATIES}

Patent Corporation Treaty done at

Washington on June 19, 1970 as

amended on September 28, 1979 as

modified on February 3, 1984 and on

October 3, 2001 7,88

Treaty Concerning the Accession of the

Republic of Croatia, Council of the

European Union, Brussels 7 November

2011

Treaty of Amsterdam amending the Treaty

of the European Union and the Treaty establishing the European Community,

10 November 1997 27

Treaty of Lisbon amending the Treaty of the

European Union and the Treaty

establishing the European Community,

13 December 2007 .. 28

Treaty of Rome of 25 March 1957 .... 26, 27

Treaty on the Functioning of the European

Union 27,82

\section{CONVENTIONS}

Berne Convention for the Protection of

Literary and Artistic Works of

September 9, 1886 completed at Paris

on May 4, 1896 revised at Berlin on

November 13, 1908 completed at

Berne on March 20, 1914 revised at
Rome on June 2, 1928 at Brussels on June 26, 1948 at Stockholm on July 14, 1967 and at Paris on July 24, 1971 and amended on September 28, 1979 88

Convention for the European Patent for the Common Market, Community Patent Convention (76/76/EEC) of 15 December 1975 (never came into force) ... 30, 31, 97, 103, 104, 105, 141, $213,215,220$

Convention for the Protection of Human Rights and Fundamental Freedoms, Rome, 4 November 1950 69,82

Convention for the Protection of Industrial Property of 20 March, 1883, as revised at Brussels on December 14, 1900, at Washington on June 2, 1911, at The Hague on November 6, 1925, at London on June 2, 1934, at Lisbon on October 31, 1958, and at Stockholm on July 14, 1967, and as amended on September 28, 1979 (Paris Convention) 159

Convention for the Protection of New Varieties of Plants of December 2, 1961, as Revised at Geneva on November 10, 1972, on October 23, 1978, and on March 19, 1991 .... 7,

Convention on Choice of Court Agreements concluded in Hague on 30 June 2005 103, 105 
Convention on Jurisdiction and the

Enforcement of Judgments in Civil and Commercial Matters signed in Brussels on 27 September 1968 ...... 26, $31,40,103,105,215$

Convention on Jurisdiction and the

Enforcement of Judgments in Civil and Commercial Matters signed in Lugano on 16 September 1988 ...... 10, $14,16,27,28,29,33,35,53,61,65$,

$72,84,88,92,94,95,98,101,106$, $109,110,115,116,117,118,119,120$, 121, 122, 124, 133, 134, 135, 139, 154, 155, 156, 162, 163, 164, 165, 166, 168, 169, 170, 171, 172, 175-82, 184,185, 186, 187, 190, 193, 195, 198, 199, 200, 201, 202, 203, 206-21, 224, 226, 227, 228, 231, 231, 235, 236, 246, 247, 248, $249,250,251,252,253,258,259,260$

Convention on Jurisdiction and the

Recognition and Enforcement of Judgments in Civil and Commercial Matters signed in Lugano on 30

October 2007 .... 10, 14, 16, 27, 28, 29, $31,33,34,35,36,37,38,39,40,41$, $42,43,45,46,47,48,50,52,53,55$, $56,57,58,59,61,62,63,64,65,67$, 70, 72, 75, 84, 92, 94, 95, 98, 106, 109, $110,115,116,117,118,119,120,121$, $122,124,128,147,164,165,166,168$, 169, 170, 171, 172, 175-82, 184, 185, 186, 187, 190, 193, 195, 198, 199, 200, 201, 202, 203, 206-21, 224, 226, 227, 228, 231, 231, 235, 236, 246, 247, 248, 249, 250, 251, 252, 253, 258, 259, 260

Convention on Private International Law, Jurisdiction and Foreign Judgments in Civil and Commercial Matters, Hague, 1999 (never came into force) ......... 103, 192

Convention on the Grant of European Patents of 5 October 1973 as revised by the Act revising art. $63 \mathrm{EPC}$ of 17 December 1991 and the Act revising the EPC of 29 November 2000 ... 8, 9,

\section{AGREEMENTS}

Agreement between the European

Community and the Kingdom of

Denmark on Jurisdiction and the

Recognition and Enforcement of

Judgments in Civil and Commercial

Matters of 19 October 2005 26

Agreement on a Unified Patent Court

(2013/C 175/01) of 20 June 2013 .... 5, $7,8,9,10,14,16,19,20,50,51,52$, $53,54,55,56,57,58,70,72,89,102$, 103, 104, 106, 107, 108, 110, 119, 129, 130, 133, 135, 146, 147, 148, 151, 161, 166. 167, 168, 169, 170, 173, 176, 197, 212, 213, 228-34, 236, 237, 239, 241, 242, 245, 246, 256-8, 259, 261

Agreement relating to Community patents 89/695/EEC done at Luxembourg on 15 December 1989 (never came into force) 31,252

Draft Agreement on the Establishment of a European Patent Litigation System (EPLA), 2004 (never came into force) 35

Draft Agreement on the European Union

Patent Judiciary of 14 May 2008

(9124/08 PI 24 COUR 19) .... 50, 107, 131, 166

Draft Agreement on the European Union

Patent Judiciary of 30 June 2008

(11270/08 PI 32 COUR 32) .......... 50, 131, 166

Draft Agreement on the European Union

Patent Court and draft Statute of 4

November 2008 (14970/08 PI 78

COUR 52) 50, 131, 166

Draft Agreement on the European and Community Patents Court and draft Statute of 8 January 2009 (5072/09 PI 1 COUR 1) $50,131,166$

Draft Agreement on the European and Community Patents Court and draft Statute, revised Presidency text of 23 March 2009 (7928/09 PI 23 COUR 29) $50,131,166$ 
Draft Agreement on a Unified Patent Court and draft Statute, Presidency text of 14 June 2011 (11533/11 PI 68 COUR 32) . 50, 131, 166

Draft Agreement on a Unified Patent Court and draft Statute, revised Presidency text of 2 September 2011 (13751/11 PI 108 COUR 48) ... 50, 107, 131, 166

Draft Agreement on a Unified Patent Court and draft Statute, revised Presidency text of 7 October 2011 (15289/11 PI 127 COUR 56) 50, 131, 166

Draft Agreement on a Unified Patent Court and draft Statute, revised Presidency text of 19 October 2011 (15539/11 PI 133 COUR 59) $50,107,131,166$

Draft Agreement on a Unified Patent Court and draft Statute, revised Presidency text of 26 October 2011 (16023/11 PI 141 COUR 62) 50,167

Draft Agreement on a Unified Patent Court and draft Statute, revised Presidency text of 11 November 2011 (16741/11 PI 155 COUR 64) $50,131,167$

Draft Agreement on the creation of a Unified Patent Court, guidance for future work of 24 November 2011 (17539/11 PI 168 COUR 71) ........ 50, 131, 167

Draft Agreement on a Unified Patent Court and draft Statute, consolidated text of 27 September 2012 (14268/12 PI 133 COUR 66) 50, 131, 167

Draft Agreement on a Unified Patent Court and draft Statute, consolidated text of 12 October 2012 (14750/12 PI 120 COUR 67) $50,132,167$

Draft Agreement on a Unified Patent Court and draft Statute, consolidated text of 14 November 2012 (16222/12 PI 146 COUR 74) 50, 107, 132, 167

Draft Agreement on the Unified Patent Court (17407/11 LIMITE PI 166, COUR 74) of 2 December 2011 with attached Non-Paper of 30 November 2011 from the Commission regarding the Relationship of the Draft
Agreement on the Unified Patent Court with Regulation (EC) NO 44/2001 Brussels I .54

Hague Agreement concerning the

International Registration of Industrial

Designs 7

Madrid System for the International

Registration of Marks and the Protocol

Relating to the Madrid Agreement

Concerning the International

Registration of Marks, adopted at

Madrid on 27 June 1989 7

Trade-Related Aspects of Intellectual

Property Rights annexed to the

Marrakesh Agreement Establishing the

World Trade Organization, signed in

Marrakesh, Morocco on 15 April 1994

(TRIPS) $82,88,159,202$

\section{DECISIONS}

Council Decision 2006/325/EC OJ L 120/22 of 27 April 2006 concerning the Conclusion of the Agreement between the European Community and the Kingdom of Denmark on Jurisdiction and the Recognition and Enforcement of Judgments in Civil and Commercial Matters 26

\section{PREPARATORY WORKS}

Memorandum amending Regulation (EU) No 1215/2012 on Jurisdiction and the Recognition and Enforcement of Judgments in Civil and Commercial Matters COM(2013) 554 final, 2013/0268 (COD) 164

Memorandum for a European Parliament and Council Regulation on the Community Design presented by the Commission COM (93) 342 final COD 463 Brussels, 3 December 1993 123,222 
Memorandum for a Council Regulation on Community Plant Variety Rights presented by the Commission COM(90)347 (90/C 244/01) Brussels

6 September 1990 128

Memorandum of the European

Communities Supplement 5/80, New

Trade Mark System for the

Community, proposed Directive and

Regulation prepared by the

Commission of the European

Communities (COM 80635 final 19

November 1980) 122,141

Memorandum on amending Council

Regulation (EC) No 207/2009 on the

Community Trademark 2013/0088

(COD) published on 27 March

2013 31,36

Memorandum on the Creation of an EEC

Trade Mark adopted by the

Commission on 6 July 1976, SEC(76)2462 July 1976 ........ 122, 141,

Memorandum on the Need for a European

Trademark System, Competence of the

European Community to create one,

Commission Working Paper, Working

Group on the Community Trademark,

October 1979,

III/D/1294/79-EN 122,141

Report on the Convention on Jurisdiction

and the Enforcement of Judgments in

Civil and Commercial Matters signed

at Brussels 27 September 1968 by P.

Jenard, Director in the Belgium

Ministry of Foreign Affairs and

External Trade, OJ of 5 March 1979 C

59/1 (Jenard report) .... 83, 86, 93, 116, $119,153,193,247,248$

Report on the Convention on Jurisdiction

and the Enforcement of Judgments in

Civil and Commercial Matters done at

Lugano on 16 September 1988 by Mr.

P. Jenard and Mr. G. Möller 90/C

189/07 (Jenard and Möller

report) 117
Report on the Convention on Jurisdiction and the Recognition and Enforcement of Judgments in Civil and Commercial Matters, signed in Lugano on 30 October 2007, by Professor Fausto Pocar, 2009/C 319/01 (Pocar report) ..... 95, 104, 114, 119, 187, 193,

Report on the Convention on the

Association of the Kingdom of

Denmark, Ireland and the United

Kingdom of Great Britain and

Northern Ireland to the Convention on Jurisdiction and the Enforcement of Judgments in Civil and Commercial Matters and the Protocol on its interpretation by the Court of Justice by Professor Dr. Peter Schlosser, OJ of 5 March 1979 C 59/71 (Schlosser report) 16, 193

\section{SCHOLARLY REPORTS}

Conflict of Laws in Intellectual Property,

The CLIP Principles, Prepared by the

European Max Planck Group on

Conflict of Laws in Intellectual

Property, 2011 252

Memorandum amending Regulation (EU)

No 1215/2012 on Jurisdiction and the

Recognition and Enforcement of

Judgments in Civil and Commercial

Matters COM(2013) 554 final,

2013/0268 (COD) ....... 39, 42, 56, 164

Transparency Proposal on Jurisdiction,

Choice of Law, Recognition and

Enforcement of Foreign Judgments in

Intellectual Property, 2009 .... 184, 189, 195, 197

\section{CJEU OPINION}

Opinion 1/09 of 8 March 2011 of the

CJEU 52, 104, 168 


\section{EVALUATION REPORTS}

Evaluation of the Community Plant Variety

Right Aquis - Final Report to the

Directorate General for Health and

Consumer Affairs, European

Commission, April 2011 ......... 35, 101,

Report on the Application of the Brussels I

Regulation in the Member States,

Ruprecht-Karls-Universität

Heidelberg, Institut für Ausländisches

und Internationales Privat- und

Wirtschaftsrecht, presented by

Prof. Dr. Burkhard Hess, Prof. Dr.

Thomas Pfeiffer and Prof. Dr. Peter

Schlosser (Munich) Study

JLS/C4/2005/03 156

Study on the Overall Functioning of the

European Trade Mark System presented by Max Planck Institute for Intellectual Property and

Competition Law Munich of 15

February 2011 ..... 64, 96, 97, 122, 140,

\section{GREEN PAPERS}

Green Paper on Alternative Dispute

Resolution in Civil and Commercial

Matters, COM (2002) 196 final ...... 82

\section{RECOMMENDATIONS}

WIPO Joint Recommendation Concerning Provisions on the Protection of Marks, and other Industrial Property Rights in Signs on the Internet, 2001 20 